\title{
Retail Mix Strategies of Minimarket
}

\author{
Ria Arifianti \\ Department of Business Administration \\ Faculty of Social and Political Sciences \\ Universitas Padjadjaran, Bandung \\ E-mail: r.arifianti@unpad.ac.id
}

\begin{abstract}
There have been many significant developments in modern retail, particularly in Bandung, which have led to increased competition among retailers. The competition not only occurs between retailers but also with large companies. One of the retail companies are minimarkets. With these conditions, the minimarket seems require a new strategy. One the strategy is the mixed retail strategy. This research uses the descriptive method. The data collection technique consisted of a literature review and field studies. The field studies that used are observations, interviews with the managers and consumers in minimarket, and also distributing the questionnaire to the consumers. The sampling technique that used is the Systematic Random Sampling. By using this method, it has found that the retail mix strategy has been worked well. But there are still many obstacles relating with the quality of goods taken as discounts, goods provided to make the exchange coupons sometimes not available and the guidelines given are unclear. Elements of mixed retail that consumers preferred are goods that used as the gift items and very useful, although sometimes the supplies are limited and fast discharged.
\end{abstract}

Keywords: retail mix strategies, minimarket

\section{INTRODUCTION}

Retailing business are the whole activities for sales goods or services to the costumers in order to fulfill their essential needs. This kind of business is rated so profitable particularly in big cities and Bandung is one of them. Bandung has proclaimed as a service city. The services are referred to education services, and also trading services in retailing business field such as minimarkets, supermarkets, and hypermarkets.

The retail formats has developed from time to time, continuously. The condition of this development applied due to the community customs who likes to use the factory goods which results in an active cash flow in trading sector and also the increasing number of customers who shopped at modern shops, especially for those who live in urban area. [1].

The development of modern retail, such as minimarkets, supermarkets, and hypermarkets, has led to the tough competition in business world. This kind of tough competition is not only occurs between retails in similar format but also with other retails with different ones. For instance, a supermarket not only competes against the other supermarket, but they also compete with hypermarkets, the department store, super store, or even traditional shops.
This condition has encourage the changes of dimensions for competition in retail business which so far has always been constituted of grocers and hypermarkets, supermarkets, minimarket, and traditional retailer. For instance, the business competition between grocers and retailers signifies the overlapping situations.

Consequently, retailers do not only compete against the other retailers but also with the other grocers who acts as retailers [2][3].

One of the retailing formats is Minimarket. Minimarkets become one of the modern markets with a very large number and its spread in almost the entire city in Indonesia. Minimarket's market target expands from metro areas into suburbs, villages, or even neighborhood.

The rapid development of minimarket format (including convenience store) has motivated the business expansion of Alfamart and Indomaret that controlled about $87 \%$ of market share. The growth of modern retail, particularly in the form of minimarket, experiences the most significant growth. Referring to the growth of store quantity in the last decade, minimarket format grows for an average of $17.4 \%$ [4].

The more developed a minimarket is the more the manager tries to find ways to keep his business running amidst the competition. One of these means is the retailing mix strategy. It is a way of selling goods and services which is distributed to the customers.

Within a retailing mix, there is retail wheel strategy. The strategy which contained in the Wheel of Retailing those are, the first is the Low End Strategy that emphasizes the relatively inexpensive price, services and facilities are limited and the buyer segments served are the price-sensitive ones. Second, the Medium Strategy which emphasizes the competitive price/ intermediate, upgraded amenities and the segment of buyers has been expanded (not just price-sensitive). Third, the High End Strategy, which emphasizes the high prices, shows the facilities and excellent service and a segment of buyers who served upscale [5].

Minimarket is put on the developmental stage. This is due to the large number for further development of various aspects one of which is the product development.

However, in the implementation of retailing mix, there are several things which become customer's complaints: the low quality of promoted products, the unclear guidelines, and uncertain promotion period related to reward exchange. 
Sometimes the supply of goods for reward exchange is unavailable as it gets closer to the due date. So it was disappointing the consumers.

This research is emphasized the development theory of Levy and Weits, because there hasn't been any research related to retail that using the theory concerned which applied in minimarket, especiallly applied in Bandung.

Consequently, the writer is motivated to conduct a research related to retailing mix strategy applied by minimarkets in Bandung.

\section{A. Research Question}

How is retailing mix strategy applied by minimarkets in Bandung?

\section{B. Research Objective}

This research is aimed to analyze the retailing mix strategy implemented by the minimarkets in Bandung.

\section{LITERATURE REVIEW}

\section{A. The Concept of Retailing Mix}

Retailing mix is related to the trading of goods/ service which is distributed to the final consumer. This strategy is applied by retailers and the trading business is prominently from retailers. Not with standing the fact that most retailing activities occur in retailer shops, retailers also sell their products by post, phone, house-to-house contact, vending machine, and various virtual means.

Retailing mix strategy is constituted of strategic elements which are used to motivate costumers make transactions with particular retailers [6].

Furthermore, the definition of retailing mix strategy can be elaborated as follow:

"[r]etailing mix strategy is the combination of factors retailers used to satisfy customer needs and influence their purchase decisions. Elements in retail mix include merchandise and service offered, merchandise pricing, advertising and promotional programs, store design, merchandise display, assistance to costumers provided by salespeople, and convenience of store's location" [7]

" $[\mathrm{t}]$ he retail mix ix the combination of merchandise, price, advertising and promotion, customer services and selling, and store layout and design that the retailer uses to satisfy the target market"[8]

"[A] Retail is the overall plan guides the firm. Such a strategy has an influence on the retailer's business activities and its response to market forces, such as competition or the economy"[5]

" [t]he marketing mix of a retailing firm has classically been called the retailing mix and consists of location and physical facilities, merchandising, pricing, promotion, services, and organization/ personnel.'[9]

\section{B. The Elements of Retailing Mix}

the elements of retailing mix are as follows [8] :

1) Combination of products. It relates to the diversity and also the durability of products which are offered by the company.

2) The price related to how the price is set in a modern retailer context.

3) Advertisement and Promotions. It relates to various promotional and advertising efforts made by the company.

4) Customer Service and Sales. It related to the service that provided by salesperson and the convenience in terms of payment.

5) Design and Layout of a Store. It related to the product's placement that can satisfy the customers.

The retailing mix strategy more specifically as " $[\mathrm{t}] \mathrm{he}$ firm's particular combination of store location, operating procedures, goods / services offered, pricing tactics, store atmosphere and customer services, and promotional methods. [5]

Other opinions are given by [3], [10],[11] who mentioned that the Wheel of Retailing has explained the emergence of new retailers, and also the disappearances of the old retailers, which will replace by the new retailers that entered the market by placing the position of low margin, low price, and low status. Retailing companies put their business facilities in the areas which are demand in low cost as well as that require less service for the costumers. This situation becomes a challenge for conventional retailers whose cost and price continuously increase from time to time.

These retailers then make innovations and successfully move their business to areas with higher rent cost, fixing up their shops' facilities and equipments, and also adding up several services for the customers. Then, they got a high margin, high price, and high retailer status which made them leave their previous positions as low margin, low price, and low status. This condition is spinning and continuously rotates [3], [10], [11].

Furthermore, in a retailing activity that there is known as the Scrambled Merchandising. It occurs when retailers/ companies adding products and increase the service which is possibly unrelated between each other; this applies to companies purely for business activity.

This strategy can be applied by following several reasons: the companies/ retailers want to improve their overall sell; they want to improve their margin in selling products and service; it related to customers who make purchase impulsively; to people who do one stop shopping; the different market target achievement; and also for alleviating the competition. This strategy can also be applied if the product offered by the company performs poorly in the market and if the company wants to attract more customers. The application of this strategy can be found in bookstores, video renter, florist, or supermarket which relates to these aspects [3]. [5] 


\section{RESEARCH METHODOLOGY}

The method used in this research is descriptive. Descriptive research conducted in this research in order to provide descriptions or illustrations which are systematic, factual, and accurate concerning the retailing strategies applied by Minimarkets. It based on the opinion that given by [12]

The technique of data collection are as follows:

\section{1) Literature study}

In order to complete the primary data, secondary data are required and thus a literature study is conducted. The secondary data is collected by studying the text books and other publications which are considered supportive such as journal articles and research findings concerning the retail development data (particularly Minimarket) from Bandung city's trading agency, Bandung city's government, and central statistical agency.

\section{2) Observation}

Observation is done by directly observing a minimarket. The steps taken are visited the three minimarkets and observing customer's behaviors to identify problems. While observing, no interview is done in order not to alter observed subjects' behavior.

\section{3) Interview}

The first thing was made during the interview is to ask questions orally to the first subject of research (consumers) regarding any complaints or problems that they faced when they performs the shopping activities. Both of managers at those Minimarkets, on the number of consumers whose shopping everyday and the retail mix strategy that the company has done. Interviews conducted with managers minimarkets and consumers takes about 30 minutes to 60 minutes.

\section{4) Questionnaire}

Questionnaires had given to the consumer as many as 30 people at each minimarkets. It aims to find out how the implementation of existing retail mix strategy in minimarkets. The sampling was systematic sampling technique. The trick is first given to the consumer first. Furthermore, the second consumer depends on the length of the first consumer charge. In this study, the first consumer has filled in about 25 minutes, and then 26 minutes, and 52 minutes and so on given to the next consumers. Techniques used in data analysis mode i.e. numbers that frequently appears.

\section{FINDINGS AND DISCUSSION}

Elements in retail mix include merchandise and service offered, merchandise pricing, advertising and promotional programs, store design, merchandise display, assistance to customers provided by salespeople, and convenience of store's location. Furthermore, the applications of retailing mix strategy are as follows:

\section{Merchandise and service offered}

Customers constantly expect to find what they need and desire in every store. Their needs and desires are varied and shops are expected to fulfill them. The function of a product management is a function which needs to be prioritized. A good product management will result in accuracy to determine offered products, product variation, brand diversity, product quantity, and supply management.

Minimarkets have selling goods between 3000 up to 5000 kinds of items. Minimarkets manage several variations of products. For example, they offer soap product from several brands.

\section{Merchandise pricing,}

Retail price is the primary factor which determines layout and this has to be set in accordance with the market target, product and service variety mixing, and the competitions. Customers who shop carefully encourage the retailers to lower their price. Afterwards, the producers are also forced to lower their price. This results in a market which is marked by discounts and big sales promotion.

On the other hand, the price of a product is relatively expensive from the costumers' perspective. They compared the price with the one in Yogja Supermarket. Yogja is the market leader in Bandung and the price in this place is deemed cheaper by costumers.

The price offered tends to be the same with the price in Alfamart or Indomaret. However, in Alfamart, the price of essential needs such as oil is relatively lower than prices in other minimarkets or supermarkets.

\section{Advertising and promotional programs,}

Advertisement is not a personal communication and it utilizes mass media (both printed and electronic) which is aimed at persuading or influencing the audience. Advertising is paid mass media channels aimed at consumers using nonpersonal communication channels such as newspaper, television, radio, direct mail and the internet, or other media [7]

Minimarkets use the television, local newspapers, and national newspapers. Notwithstanding this, occasionally the advertisement does not convey the intended message. This, according to the costumers' perception, is because they do not pay attention to minimarket advertisement.

Sales promotion in a marketing activities means which can be through media or non-media to persuade costumers to give their trial and error's products, increasing costumers' demand, or enhancing product's quality.

Promotions that had done by minimarket are typically contingent on a particular moment. For example, in order to celebrate the Ramadhan, Alfamart offers a special price for Marjan syrup which can be purchased by Rp. 500,-, as if a customer buys the sponsor's products such as Pepsodent, Biore, etc. On the other hand, Indomaret also offers plastic container for Rp. 9.000,-. Yomart offers special price if the customer collects 40 coupons which can be traded with Filma oil or Sunlight dishwashing soap and 60 coupons to be traded with a shopping bag. Such collection of point does not use paper coupon, it uses membership card where the point information is accessible via internet or provided media.

However, the product given sometimes has a low quaity or nearing its expiration date. It becomes a complaint from the 
customers. The promotion period is sometimes unclear or uninformed. Thus, they only realize it when they go to the shop.

Moreover, in terms of trading point/ stamp with a product, occasionally the offered product is no longer available anymore, particularly when it nears the due date for coupon exchange.

\section{Store design,}

A store design is relates to a shop's exterior and interior design. The exterior consist of physical building that can be seen from its shape, such as a building form, the access door, and so on. The size of minimarket is less than 200 meters. Each of minimarket has its own uniqueness in color terms. Alfarmart has building that painted in red. Indomaret has building that painted in the combination of blue and white. Yomart has building that painted in the combination of yellow and green.

Secondly, it is the interior of the shop itself. The interior design of retail shop basically ought to match its exterior design. It is essential to maintain the balance of image that has been formed from the outside of the building. The elements of interior design are the aesthetics, room design, and layout.

Shop's aesthetic has associated with: First, how do the shop's facilities can create impressions that affecting costumers' feeling. This is related to the shop's nuance. Minimarkets have wide corridors which provide the comfortable conditions for the shoppers. This is done to facilitate the customer to shop easily. The shopping comfort is become a top priority for the company and this will bring about benefits for the company.

The second factor is the aesthetics of room design. It relates to the room usage compared to the retailer's production level. The room design relates to the use of room which is supported by lighting, decorations, and cleanliness. Minimarket has arranging the room like the other forms of retail that is using the hallways, so it seems more spacious. Besides the addition of dedicated space for the consumer that their tables and chairs are used by consumers to enjoy beverages or meals offered. At Alfamart, they are usually placed on the porch of the store, while Indomaret placed it inside the store.

\section{Merchandise display,}

Merchandise display relates to layout. Layout has something to do with: First, classification of products in a similar group. The minimarkets have put homogeneous products at the same area. For example, one corridor is allocated for drinks from various brands.

The second element of layout is the overall layout. In managing the products offered, it is essential that the manager should pay attention to the lighting. There is a tendency that the less light reaches products on the bottom part of the shelf. This is done in order to maintain the vision of the customer.

The third one is to determine the room width which will be allocated by a group of products. This is typically contingent on the decision between the companies (minimarket) and the suppliers. This is due to being related to the number of products to be placed.
The fourth is to select location for products in the shop. Products' placement is also made in accordance with supplier's demand. It can be in form of Gondola or listing fee. Listing fee is the cost or renting cost for a space to display products.

The fifth is to plan the most advantageous management for products' grouping. It depends on the agreement between a supplier and a minimarket. If there is a promotion of a particular product, the product will be placed laid at the entranceway or the cashier. This is to remind the customers that there is a price off.

To make it easier for customers to locate a product, a sign is typically put in form of arrow sign or above of the shelves. This is a way to make customers feel easy to locate the products they want to purchase. Sign board will influence the level of ease a costumers experience in locating the product they are looking for.

Nevertheless, costumers sometimes do not pay attention to the sign system. They say that the sign board is put way too high and therefore illegible for them.

\section{Assistance to customers provided by salespeople,}

This is related to the customer service. The service covers to what extent the service can be provided before a customer does the shopping, while they are shopping, and after they have shopped in a timely manner. If the customer thinks that the perceived service exceeds their expectation, they will be satisfied with the service provided. However, perceptions may differ between one to another. It depends on the customers' experiences, backgrounds, and their underlying expectations. Therefore, retailers should put their best effort to enhance customers' perceived service.

Minimarkets provide an excellent service. For instance, when customers entered the shop, the welcome's greeting is always given by the shopkeeper. Moreover, after they have done shopping, they will be offered products with discount. Other amenities are giving Alfamart their membership card as the card I, and Indomaret also issued special cards of Indomaret.

\section{Convenience of store location}

To choose a location is a very essential decision to be made in a retail business. A right or wrong location is the start of the success or failure of the business. Strategic location, being adjacent to the market target and location security is the targets of a location.

To analyze an area, criteria to be referred to is the one that proposed by Taufiq Amir [1]:

- Primary trading area includes majority of customers within the reach of the chosen area and these customers are those whose purchasing potential is the highest.

- Secondary trading area is refers to who will be the potential customers that located outside of the primary area. Typically, the time required to reach the shop is much longer compared to the time needed for primary area. 
Also, it can be done with the location analysis. Broadly speaking, there are three options about retailer are presented with:

- In a shopping mall (mall, trade center, shop complex, etc)

- In the midtown/ or center of activities

- In an area where the shop exists independently and separately

Minimarkets as retailers or modern shops expand their development strategy to cities, districts, villages, even to remotes areas. This is done as a consequence of abundance of hypermarket and supermarket formats in the metro area. Also, minimarkets intentionally attempt to approach their final customers who are residing in housings. Furthermore, they also target at students. This can be seen from the provision of space or benches which are usually used by students to hang out.

Furthermore, based on interviews with customers, retail mix elements that customers preferred the item as a gift is interesting and useful to use though sometimes its supplies are limited and quickly exhausted. They are really like the merchandise offered by supermarkets because it different than others. For example, when Alfamart offers a collection of 10 pieces for a coupon redeemable for a key chain of Hello Kitty or Doraemon's doll miniature or a bowl by paying a special price, the articles are quickly discharged invaded by consumers. Indomaret offers redemption at reduced price of goods such as mugs or towels or another, then the goods are quickly discharged.

\section{CONCLUSION AND SUGGESTION}

\section{A. CONCLUSION}

The application of retailing mix strategy is deemed done well by the minimarkets. It is indicates that the retailing mix has been done in accordance with the existing retail concepts. However, in its application, there are some weaknesses such as product's placement which occasionally confuses the costumers.

The period of a sales promotion is unclear. The quality of discounted products is not good and there is a tendency that these products are easily broken. The supply of reward product is sometimes insufficient.

\section{B. SUGGESTIONS}

1) It is vital that the minimarket managements need to pay more attention about the discounted product quality. For example, management should check or seek for informations concerning the durability of a product to the supplier. So, when the product is discounted, it will not be easily broken or pass its expiration date.

2) The manager of each minimarket must check inventory used to exchange the goods.

3) Offered product's location sign system should be taken into consideration particularly how to provide a clear sign system which makes shopping is easier for customers.
4) There is more research on retail mix strategies in other cities like Surabaya or Jakarta.

\section{REFERENCE}

[1] Taufik Amir. 2004. Manajemen Retail. Penerbit PPM. Jakarta. Pg 1-2

[2] Ria Arifianti. 2006. Pengaruh Strategi Bauran Eceran terhadap Hasil Penjualan Pakaian Jadi di International Trade Centre (ITC) di Kota Bandung. Tadulako. Palu

[3] Ria Arifianti. Dwi Kartini, Tuhpawana, Yunizar. 2010. Gaya Hidup Hedonis. UNPAD PRESS, Bandung. Pg 10-20

[4] Office of Chief Economist. 2014. Perdagangan Ritel. Industry Update. Bank Mandiri. Pg. 1-2

[5] Berman. Barry and Joel R. Evans. 2004, Retail Management A Strategic Approach Eighth Edition. Macmillan. New York.. Pg. 105-106

[6] Bob Foster. 2008. Manajemen Ritel. Alfabeta. Bandung. Pg. 2-20

[7] Levy, Michael. Barton A. Weitz. 2009. Retailing Management. McGraw-Hill Irwin. North America pg 6-61.

[8] Dunne. Patrick M. and Robert F. Lusch. 2005. Retailing Fifth Edition. South Western Thomson. Pg 50-51

[9] Davidson. William. R. Daniel J. Sweeney. Ronald W. Stampfi. 1988. Retailing Management. Sixth Edition. John Wiley \& Sons. Amerika. Pg. 66

[10] Schoell, William, M. 1990. Marketing 4th edition.-------------------. Allyn and Bacon, A Division of Simon \& Schuster, Inc.

[11] Sopiah. Syihabudhin. 2008. Manajemen Bisnis Ritel. Penerbit Andi. Yogyakarta. Pg. 12-20

[12] Aaker. David A., V. Kumar, George S. Day. 2004. Marketing Research Seventh Edition. John Wiley \& Sons, Inc. New York pg. 71-73. 